\title{
EFFECTS OF CREDIT ON ECONOMIC GROWTH, UNEMPLOYMENT AND POVERTY
}

\author{
Mangasa Augustinus Sipahutar ${ }^{1}$, Rina Oktaviani², \\ Hermanto Siregar ${ }^{2}$, Bambang Juanda ${ }^{2}$
}

${ }^{1} \mathrm{PhD}$ candidate, Rural and Regional Development Planning Science, Faculty of Economics and Management, Bogor Agricultural University (IPB), Bogor ${ }^{2}$ Faculty of Economics and Management, Bogor Agricultural University (IPB), Bogor

Correspondenc E-mail: mangasaaugustinus@ymail.com

Recieved: March 2016; Accepted: June 2016

\begin{abstract}
Effect of credit on economic growth, unemployment and poverty provides evidence from Indonesia on the role of banks credit for promoting economic growth and reducing both unemployment and poverty. To document the link between banks credit and economic growth, we estimate a VAR model and variance decompositions of annual GDP per capita growth rates to examine what proxy measures of banks credit are most important in accounting for economic growth over time and how much they contribute to explaining economic growth. We also estimate an ECM to document the relationship between banks credit to both unemployment and poverty. This paper revealed bi-direction causality between banks credit and economic growth. Banks credit promotes economic growth and economic growth affects credit depth and financial development. Furthermore, banks credit is a growth accelerating factor on Indonesian economic growth. Banks credit is an endogenous growth and a good predictor on Indonesian economy. Our estimation model explained that credit allocated by banks increases business escalation to the real sectors then promotes economic growth, decreases unemployment rate through increasing in labor demanded, increases income and then decrease poverty. This overall transmission mechanism just occurred through presence of banks credit by increasing money supply to the real sectors, promotes growth and social welfare.
\end{abstract}

Keywords: banks credit, economic growth, growth accelerating factor, poverty, unemployment JEL Classification: E51, E52, E58, F43

\section{Introduction}

An extensive literature has established the relationship between financial intermediary on economic growth. Financial intermediary or banks credit has a strong positive effect on economic growth. Banking intermediary overcome transaction costs and informational asymmetries to reduce liquidity constraints and improve the allocation of capital (Fase and Abma, 2003). The positive effect on economic growth is obtained through both greater physical capital accumulation and greater productivity growth (Levine, 1997; Levine and Zervos, 1998; Beck et al., 2000; Levine, 2003; Beck and Levine, 2004).
The main function of banking intermediary is to facilitate the transmission of savings from the surplus to the deficit. The consumers who save money, and the latter are the entrepreneurial and government sectors which borrow money, with the banking sector channeling this process appropriately. The banking institution main role in this process of intermediation is to reduce the asymmetry of information for lenders and borrowers and to bring about allocation of funds to the most productive opportunities, thus increasing economic efficiency and social welfare (Fase and Abma, 2003; Levine, 2003; Rioja and Valev, 2014). According to endogenous growth 


\section{Jurnal Ekonomi Pembangunan, 17 (1), Juni 2016, 37-49}

theory, however, banking intermediation plays a more specific role through the financing of research and development as well as investment in human capital (Pagano, 1993;Barro and SalaiMartin, 2004).

There is strong, positive and causality relationship between financial development and economic growth (King and Levine 1993b). This evidence suggest that initially, the level of financial development predicts economic growth, indicating a causal relationship from financial development to economic growth in the early stages of economic development. As Bernanke (1993) described that banks are special, many economists have suggested that banks and similar institutions play a particularly central role in credit markets. Banks had expertise in conveying the saving of relatively uninformed depositors to users (real sectors of the economy) that are information-intensive and particularly hard to evaluate.

Banking institution is the channel which central bank determined its monetary policy. Monetary policy transmission mechanism that affected aggregate demand of the economy transformed effectively through banking intermediation (Bernanke and Blinder, 1992; Bernanke, 1993; Bernanke and Gertler, 1995, 1999; Bernanke and Mihov, 1998). The effectiveness of the role of banking intermediary and banks credit to the real economy sectors is really depend on its responsiveness to the policy made by central bank to affect the overall economy. It means that banking institutions has an ability to avoid time-lag between the monetary policy and its effect to the real economy sectors such as inflation, unemployment, poverty and macro-prudential.

The significant role of banks credit on economic growth was also described by Jayaratne \& Strahan (1996) who found that the regulation in financial markets influenced growth for the United States directly. They examined the impact of less rigid banks branch regulation in the United States on regional economic growth in individual states. They found a positive effect on per capita growth through improvement in the quality of banks credit. This result implies that the improvement in the quality of banks credit is the main channel through which economic growth is influenced, indicating causality from financial development to economic growth (King and Levine, 1993a,b; Demetriades and Hussein, 1996; Fase and Abma, 2003; Fernandez et al., 2012).

Besides the important role of banks credit on economic growth, stock market offer empirical evidence for the importance of stock market development to output growth (Levine and Zervos, 1998; Fase and Abma, 2003; Beck and Levine, 2004; Rioja and Valev, 2014). Eventhough banks credit and stock market have positive effect on economic growth, banks credit has stronger effect on economic growth than stock market (Arestis et al., 2001).

Beck et al. (2000) found that in different countries the extent of stock market development highly correlates with the development of banks, nonbank financial institutions, pension funds and insurance companies. Japan, the United States and the United Kingdom have the most developed stock markets, but Colombia, Venezuela, Nigeria, and Zimbabwe have the less developed stock markets and, according to these authors, the growth rates of the countries considered reflect this differences significantly. Studied the empirical relationship between measures of stock market liquidity, size, volatility and integration with world capital markets on the one hand, and economic growth, saving rates, improvements in productivity and capital accumulation, on the other hand, Levine and Zervos (1998), described that for 47 developing and developed countries in the sample period 1976-1993, stock market liquidity and banks credit were positively and significantly correlated with economic growth, capital accumulation and productivity increases. Stock market size, volatility and integration with world capital markets, however, were not significantly correlated with economic growth and productivity increases. 


\section{Jurnal Ekonomi Pembangunan, 17 (1), Juni 2016, 37-49}

The remainder of this paper is structured as follows. Section 2 describes method and summary statistics. Section 3 presents results and discussion, and our conclusions and policy implications are in Section 4.

\section{Method and Summary Statistics}

This paper used data of Indonesian economy over the period 1990-2014 [http://www.bi.go.id/ $i d / s t a t i s t i k / s e k i]$ from Central Bank of Indonesia (BI) described the banks credit, and [http:// www.bps.go.id/linkTabelStatis/view/id] from Indonesian Central Bureau of Statistics (BPS), described Indonesian GDP, nominal and real GDP, real GDP growth per capita, unemployment rate and poverty rate. We used econometrics method developed by King and Levine (1993b); Levine et al. (2000); Beck and Levine (2004), which described relationship model between credit depth (ratio between banks credit to nominal GDP) and real GDP growth per capita.

\subsection{Effect of Credit Depth on Economic Growth}

To investigate the causality relationship between credit depth and economic growth, we use a VAR (Vector Auto-Regressive) model as follows :

$\mathrm{NGR}_{t}=\alpha_{1}+\alpha_{2} \mathrm{CRE}_{t}+\alpha_{3} \mathrm{NGR}_{t-n}+\varepsilon_{1 t}$

$\mathrm{CRE}_{t}=\beta_{1}+\beta_{2} \mathrm{NGR}_{t-n}+\beta_{3} \mathrm{CRE}_{t-n}+\varepsilon_{2 t}(2)$

where $\mathrm{NGR}_{t}$ is Indonesian real economic growth per capita at year $t, \mathrm{CRE}_{t}$ is credit depth measured by the ratio of banks credit to nominal GDP at year $t, \mathrm{NGR}_{t-n}$ is real economic growth per capita at year $t-n, \mathrm{CRE}_{t-n}$ is credit depth at year $t-n$ and $\varepsilon$ is error term. Credit depth at year $t$ promotes economic growth at year $t$, moreover, economic growth at year $t$-n promote credit depth at year $t$. The matrix form of model is as follows:

$$
\begin{aligned}
& \mathrm{Y}_{t}=\left[\begin{array}{l}
\mathrm{NGR}_{t} \\
\mathrm{KRE}_{t}
\end{array}\right] ; \mathrm{A}_{0}=\left[\begin{array}{l}
\alpha_{11} \\
\alpha_{21}
\end{array}\right] ; \mathrm{A}_{1}=\left[\begin{array}{l}
\alpha_{12} \alpha_{13} \\
\alpha_{22} \alpha_{23}
\end{array}\right] ; v_{t}=\left[\begin{array}{l}
v_{1 t} \\
v_{2 t}
\end{array}\right] \\
& \text { or } \\
& \mathrm{Y}_{t}=\mathrm{A}_{0}+\mathrm{AY}_{t-n}+\mathrm{v}_{t}
\end{aligned}
$$

Refer to the estimation model (equation 3 ), we found that the relationship between credit depth and economic growth is VAR(1) as presented in Table 1.

Table 1 VAR estimation on the causality relationship between credit depth (CRE) and real GDP growth per capita (NGR)

\begin{tabular}{ccc}
\hline & $\Delta \mathrm{NGR}$ & \multicolumn{1}{c}{$\Delta \mathrm{CRE}$} \\
\hline$\Delta \mathrm{NGR}_{-1}$ & -0.757464 & -0.447334 \\
& $(0.17568)$ & $(0.09480)$ \\
& {$[-4.31164]$} & {$[-4.71875]$} \\
& & \\
& & \\
& 0.682732 & 0.578140 \\
& $(0.29946)$ & $(0.16160)$ \\
& {$[2.27985]$} & {$[3.57770]$} \\
$\mathrm{C}$ & & \\
& 0.291456 & -0.190715 \\
& $(1.98207)$ & $(1.06956)$ \\
& {$[0.14705]$} & {$[-0.17831]$}
\end{tabular}

Standard errors in ( ) ; t-statistics in []

Our VAR model described that the change in economic growth at year $t$ is stimulated by positive and significant of the change in credit depth at year $t-1$, and the change in credit depth at year $t$ is affected by the change of credit depth at year $t-1$. At the beginning period, the shocks of economic growth at $\Delta \mathrm{NGR}_{-1}$ is responded negatively by economic growth at $\Delta \mathrm{NGR}_{t}$, but credit shocks at $\triangle \mathrm{CRE}_{-1}$ is positively responded by economic growth at $\Delta \mathrm{NGR}_{t}$ (Figure 1). 
Response to Cholesky One S.D. Innovations \pm 2 S.E.

Response of $D(N G R)$ to $D(N G R)$

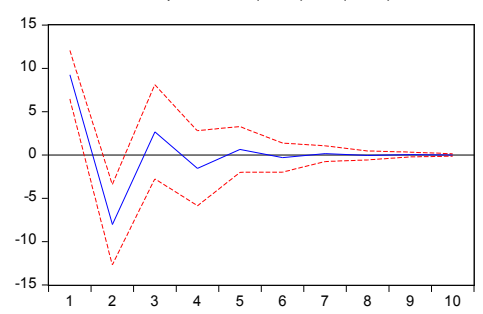

Response of $D(K R E)$ to $D(N G R)$

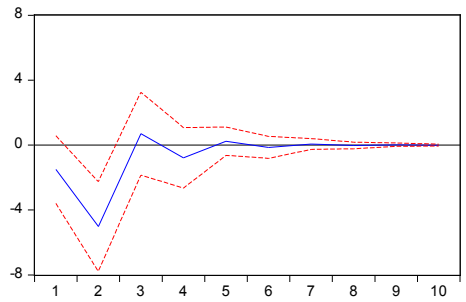

Response of $D(N G R)$ to $D(K R E)$

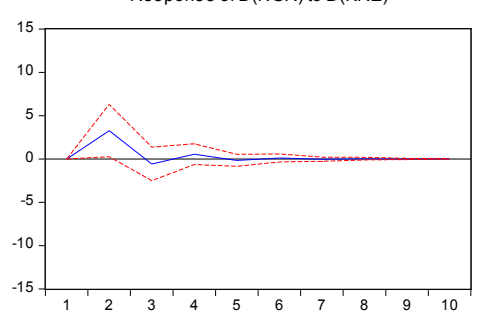

Response of $D(K R E)$ to $D(K R E)$

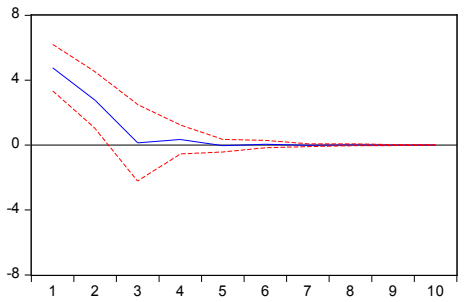

Figure 1. Impulse Response Factor (IRF) on the relationship between credit depth (CRE) and real GDP growth per capita (NGR)

The shocks of economic growth at $\Delta \mathrm{NGR}_{-1}$ is responded negatively by credit depth at $\Delta \mathrm{CRE}_{t}$ since the beginning period before responded positively after years. Nevertheless, credit shocks at $\Delta \mathrm{CRE}_{-1}$ is responded positively by $\Delta \mathrm{CRE}_{t}$ from the beginning, but its response declines there after to the steady state. This means that for banks credit expansion, banking institutions in Indonesia tended to use previous growth to determine their future growth.

Variance Decomposition
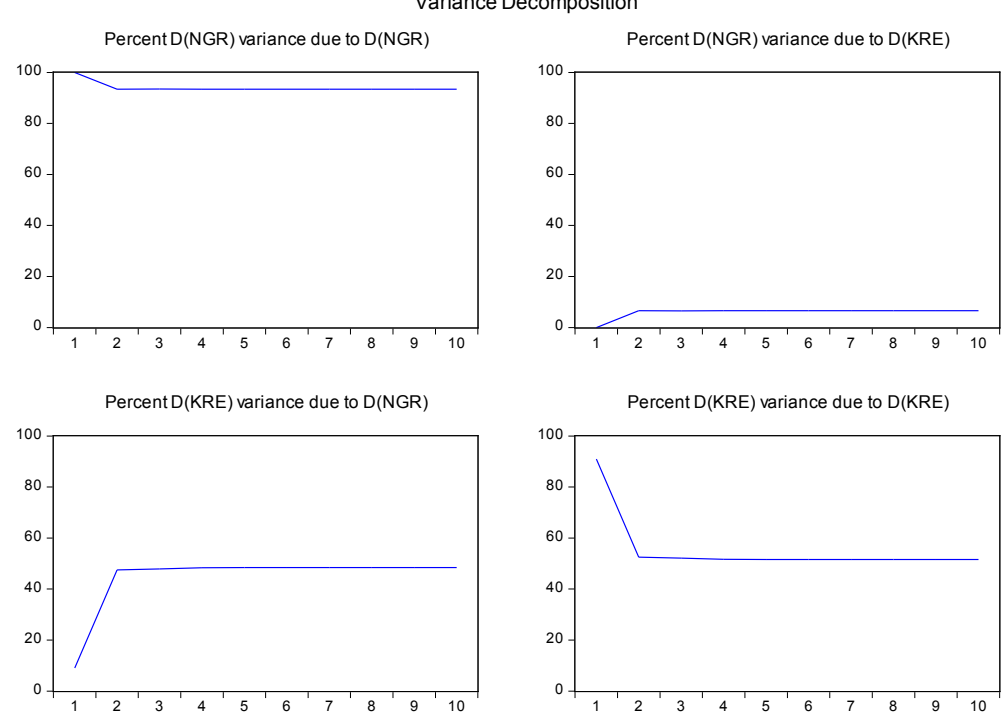

Figure 2. Forecast Error Decomposition Variance (FEDV) on the relationship between credit depth (CRE) and real GDP growth per capita (NGR) 


\section{Jurnal Ekonomi Pembangunan, 17 (1), Juni 2016, 37-49}

According to variance decomposition (Figure 2), the main source to economic growth is the economic growth shocks it-self, but for banks credit, the shocks stemmed from both credit depth it-self and economic growth that contributing similarly after the first year. Eventhough, at the beginning, for banks credit, the shocks of credit depth contributes $91 \%$ and only $9 \%$ from economic growth. It means that to stimulate credit expansion, both credit depth and economic growth are important for achieving the sustainability of Indonesian economic growth. Using Granger causality, we found bi-direction causality between credit depth and economic growth. Banks credit promotes economic growth significantly, and economic growth affects credit deepening significantly (Table 2).

Table 2. Granger causality on the relationship between credit depth (CRE) and real GDP growth per capita (NGR)

\begin{tabular}{lccc}
\hline Null Hypothesis: & Obs & F-Statistic & Prob. \\
\hline CRE does not & & & \\
Granger Cause & 23 & 4.06563 & 0.0574 \\
NGR & & & \\
NGR does not & & & \\
Granger Cause & & 30.2505 & $2 . \mathrm{E}-05$ \\
CRE & & & \\
\hline
\end{tabular}

Bi-direction causality between credit depth and economic growth is an important indicator to Indonesia macroeconomy perspectives that sustain economic growth will be able to achieve when banking institution let responsiveness to the Indonesian economy and development issues due to their role as credit channel for monetary policy transmission mechanism framework determined by Bank Indonesia as central bank of Indonesia. Causality relationship also meant that Indonesian banks will be growing higher when supported by sustain economic growth. Banking intermediation will run to promote economic growth through real sectors of economy as transmission channel, and banks will achieved higher performance through financial development induced by higher real sectors escalation.

\subsection{Effect of Credit Depth on Unemployment and Poverty}

To investigate the effect of credit depth to unemployment and poverty, we use an ECM (Error Correction Mechanism) as follows :

$\mathrm{NUNE}_{t}=\rho_{1}+\rho_{2} \mathrm{CRE}_{t-n}+\mu_{2 \mathrm{t}}$

$\mathrm{NPOV}_{t}=\gamma_{1}+\gamma_{2} \mathrm{CRE}_{t-n}+\mu_{1 \mathrm{t}}$

where $\mathrm{NUNE}_{t}$ is unemployment rate at year $t$, $\mathrm{NPOV}_{t}$ is poverty rate at year $t, \mathrm{CRE}_{t}$ is credit depth measured by the ratio of banks credit to nominal GDP at year $t$, and $\mu$ is error term. The model described that credit depth at year $t-n$ will affect decreasing of both unemployment rate and poverty rate at year $t$.

According to estimation model (equation 4), we found co-integration relationship between credit depth and unemployment (Table 3). In the long-run estimation, increasing by one bases point of credit depth at $\mathrm{CRE}_{-1}$ will affect decreasing by 0.12 bases point of unemployment rate.

Table 3. Regression in difference model estimation on the relationship between credit depth (CRE) and unemployment rate

\begin{tabular}{ccccc}
\multicolumn{5}{c}{$(\mathrm{NUNE})$} \\
\hline & \multicolumn{5}{c}{ Std. } \\
Variable & Coefficient & Error & t-Statistic & Prob. \\
\hline CRE $_{-1}$ & -0.129099 & 0.024023 & -5.374071 & 0.0000 \\
$\mathrm{C}$ & 11.58332 & 0.881091 & 13.14657 & 0.0000 \\
\hline
\end{tabular}

We found that there is a significant negative relationship between credit depth at year $t-1$ and unemployment rate at year $t$. However it has significant negative effect in the long-run, its effect is not significant in the short-run through ECM estimation (Table 4). Estimation model revealed that there is a correction error to achieving longrun equilibrium where $52 \%$ adjustment occurred at the first year after credit allocation and the remainder $48 \%$ will be corrected after that. 
Avalaible online at http://journals.ums.ac.id

Jurnal Ekonomi Pembangunan, 17 (1), Juni 2016, 37-49

Table 4. ECM estimation on the relationship between credit depth (CRE) and unemployment rate (NUNE)

\begin{tabular}{ccccc}
\hline Variable & Coefficient & Std. Error & t-Statistic & Prob. \\
\hline$\Delta \mathrm{CRE}_{-1}$ & -0.013925 & 0.032061 & -0.434320 & 0.6689 \\
$\mathrm{ET}_{-1}$ & -0.521164 & 0.154809 & -3.366506 & 0.0032 \\
$\mathrm{C}$ & 0.161647 & 0.226416 & 0.713936 & 0.4839 \\
\hline
\end{tabular}

According to our estimation model at equation 5, we found co-integration in the relationship between credit depth and poverty rate (Table $5 \& 6$ ). There is significant negative effect of change in credit depth to poverty rate. Increasing the change of credit depth by one bases point will affect significant decreasing in poverty rate by 0.32 bases point. Our estimation model also revealed that there is a correction error to achieving long-run equilibrium where $56 \%$ adjustment occurred at the first year after credit allocation and $44 \%$ the remainder will be corrected after that.

Table 5. Regression model estimation on the relationship between credit depth (CRE) and poverty rate (NPOV)

\begin{tabular}{ccccc}
\hline Variable & Coefficient & Std. Error & t-Statistic & Prob. \\
\hline$\Delta \mathrm{CRE}$ & -0.323209 & 0.081550 & -3.963314 & 0.0007 \\
$\mathrm{C}$ & 15.56963 & 0.572031 & 27.21817 & 0.0000 \\
\hline
\end{tabular}

Table 6. ECM estimation on the relationship between credit depth (CRE) and poverty rate (NPOV)

\begin{tabular}{ccccc}
\hline Variable & Coefficient & Std. Error & t-Statistic & Prob. \\
\hline $\mathrm{C}$ & -0.165976 & 0.458237 & -0.362205 & 0.7212 \\
$\Delta \mathrm{CRE}$ & -0.139009 & 0.077476 & -1.794232 & 0.0887 \\
$\Delta \mathrm{ET}_{-1}$ & 0.560690 & 0.207714 & 2.699339 & 0.0142 \\
\hline
\end{tabular}

\section{Results and Discussions}

Credit facility that allocated by both banks and other financial institutions correlated to productivity and capital stock per labor. However credit facility correlated to capital stock per labor, it does not affect capital stock growth rate and labor growth rate. According to Pagano (1993), this evidence due to the effect of banking and other financial institutions to economic growth through saving growth rate. Saving accumulation at the previous period will be shedding by banks to increase the escalation of business entities in real sectors to promote economic growth. Investment through saving accumulation will promote economic growth.
On Indonesian economic growth perspectives, there is a significant positive causality relationship between banks credit and economic growth. The ratio between banks credit to nominal GDP (credit depth), promotes economic growth. Arestis et al. (2001), explained that banking and stock market have positive effects on economic growth. Eventhough both banking and stock market affect economic growth, banks credit has a stronger effect on economic growth than stock market. This can be occur due to the ability of banking system to access the whole economy sectors such as consumers, small and medium enterprises, and corporate entities, while stock market prefer the intermediation to the corporate scale entities. 


\section{Jurnal Ekonomi Pembangunan, 17 (1), Juni 2016, 37-49}

We found a VAR(1) estimation model about the causality relationship between credit depth and Indonesian economic growth. It explained that economic growth depends on how far the change in credit depth at $\Delta \mathrm{CRE}_{-1}$ to increase the change in economic growth at $\Delta \mathrm{NGR}_{t}$. Increasing in the change of credit depth at $\Delta \mathrm{CRE}_{-1}$ has positive effects to the change of economic growth but increasing in the change of economic growth at $\Delta \mathrm{NGR}_{-1}$ will decrease economic growth at $\Delta \mathrm{NGR}_{t}$. Meanwhile, increasing in the change of credit depth at $\Delta \mathrm{CRE}_{-1}$ has positive effects to the change of credit depth at $\Delta \mathrm{CRE}_{t}$, but increasing in the change of economic growth at $\Delta \mathrm{NGR}_{-1}$ will decrease the change of credit depth at $\Delta \mathrm{CRE}_{t}$. Furthermore, the estimation model explain that when the change of economic growth increases at $\Delta \mathrm{NGR}_{-1}$, it will affect decreasing on economic growth at $\Delta \mathrm{NGR}_{t}$. This evidence means that Indonesian economy will be stay away from overheated state due to the automatically correction of the economic growth at $\Delta \mathrm{NGR}_{-1}$ and revealed that the real sector has just stimulated by the credit allocated by the banking system.

Our VAR model also explained that credit depth revealed the similar response as economic development does. When there is an increasing in the change of credit depth at $\Delta \mathrm{CRE}_{-1}$, it will promote the change in economic growth at $\Delta \mathrm{NGR}_{t}$ significantly. Meanwhile, when there is a higher change in economic growth at $\Delta \mathrm{NGR}_{-1}$, it will affect a decreasing on credit depth at $\Delta \mathrm{CRE}_{t}$. This evidence explained that financial development in banking institutions will be automatically corrected by the change of economic growth at $\Delta \mathrm{NGR}_{-1}$. Banking expansion on credit just has been running by credit depth one standard deviation at $\triangle \mathrm{CRE}_{-1}$.

Based on our VAR model, we found that there is trade-off between the change of credit depth at $\triangle \mathrm{CRE}_{t}$, the change of economic growth at $\Delta \mathrm{NGR}_{t}$ and the change of economic growth at $\Delta \mathrm{NGR}_{-1}$. The presence of trade-off will avoid Indonesian economy from overheated state and credit crunch through automatically credit rationing. It means that correction factor to the credit crunch is the presence of credit rationing inside the model. This evidence affected a good circumstances to the Indonesian economy when financial stability in macro-prudential framework stems from automatic correction coming up from the link between credit depth and economic growth (Bernanke and Lown 1991; Bernanke, 1993).

According to Impulse Response Factor (IRF), there is negative response of credit depth to economic growth from the first to the third year, and move with oscillation pattern toward equilibrium state. Meanwhile, there is a positive response of economic growth to credit depth since the first year, move higher at the second year and disappear slowly to the equilibrium state. These response factors explain that there will be no permanent effect between shocks of both credit depth and economic growth in Indonesian economy. It means that when designing Indonesian economic development, both banks credit and economic growth have to be well consider for sustain economic growth.

On Indonesian economic growth, we found that the main source of economic growth variance is economic growth it-self. This VAR model indicated that Indonesian economy agreed with macroeconomic theory that aggregate output of economy are consumption, investment, government spending and net export. Eventhough the contribution of banks credit just only $6.5 \%$ to the economic growth variance decomposition, their contribution gave us an explanation that banks credit is a multiplier in economy to promote economic growth (Bernanke, 1993; King and Levine, 1993b; Bernanke and Gertler, 1999; Beck et al., 2008; Aghion et al., 2010; Woodford, 2010). Banks credit stimulates the acceleration of economic growth through its transformation to become capital and liquidity in the real sectors. Banks credit is growth accelerating factor to the Indonesian economy. Banks credit affected not 


\section{Jurnal Ekonomi Pembangunan, 17 (1), Juni 2016, 37-49}

only the scale of their debtors. Banks credit also helped debtors to achieve higher productivity, efficiency and effectiveness at the overall business relationship with their business counterparts and promote an efficient and effective value chain both vertical and horizontal. Banks credit accelerate the real sectors to expand their economic of scale and promote higher economic growth.

For banks credit, eventhough the contribution of economic growth is just relatively small at the first year, but since the second year, the composition of both economic growth and credit depth becomes relatively equal. Both economic growth and credit depth contribute by $48 \%$ and $52 \%$ to credit depth in the next period. It means that both economic growth and credit depth are the main source of banks credit variance itself. Economic growth has an important role for banks to enhance the intermediary function and financial development (Bencivenga and Smith, 1991; Pagano, 1993; Benhabib and Spiegel, 2000; Beck and Levine, 2004).

The growth of economy that supported by banks credit could also be explained by the role of banks credit to affect an increasing in labor demand due to the enlargement of economic of scale at real sectors. Banking institution as credit transmission channel affects real sectors directly through financing on capital and liquidity to achieve higher output (Bernanke, 1993; Bernanke and Gertler, 1999). The ability of banks credit to transform to being capital and liquidity make a possibility of real sectors to promote an increasing on labor demand.

According to our estimation model, we found a significant negative effect of banks credit to unemployment rate. Increasing in credit depth at $\mathrm{CRE}_{-1}$ decrease unemployment rate significantly at $\mathrm{NUNE}_{t}$. Our ECM estimation model explained that $52 \%$ of short-run fluctuation will be corrected at the first year toward equilibrium state. The magnitude of correction error at the first year described that banks credit has an important role to decrease unemployment rate since the beginning of the credit allocation. Transformation of banks credit to become capital and liquidity stimulates an increasing on labor demanded and decrease unemployment.

Furthermore, increasing in labor demanded stimulated by banks credit results an increasing in income and finally decrease poverty. The important description about the model estimation is, for decreasing poverty, the main factor is not the magnitude of the credit depth at year $t$ - 1 but the change of the credit depth. Increasing the change of credit depth $\triangle \mathrm{CRE}$ by one bases point will decrease poverty NPOV by 0.32 bases point and $56 \%$ of long-run fluctuations is corrected at the first year toward equilibrium state.

The estimation model explained that credit allocated by banks increases business escalation in real sectors, then promote economic growth, decrease unemployment rate through increasing in labor demanded, increasing income and then decreasing poverty rate. This overall transmission mechanism just occurred through presence of banks credit by increasing money supplied to the real sectors of economy, and promoting both economic growth and social welfare (Benhabib and Spiegel, 2000; Chodorow-Reich, 2014).

The effect of banks credit on increasing economic growth, decrease unemployment and poverty is based on standard IS-LM theory of macroeconomics (Blanchard and Johnson, 2013). Based on IS-LM model, ceteris paribus interest rate, expansion in fiscal policy will stimulate banks credit to increase. Banking institution will respond positively to fiscal expansion policy by increasing credit allocated to the real sectors particularly to the economy sectors where the fiscal policy was expanded. Increasing in banks credit furthermore increased money supplied and shifted both IS and LM curve up. The shifting of both IS and LM curve simultaneously will cause increasing in output. This mechanisms also occurred in AD-AS model. Based on AD-AS model, ceteris paribus price, fiscal expansion will be responded by banks credit to increase money supplied by financing the real sectors. Banks credit promote expansion of business in real 


\section{Jurnal Ekonomi Pembangunan, 17 (1), Juni 2016, 37-49}

sectors due to the enhancement on capital and liquidity and let both $\mathrm{AD}$ and $\mathrm{AS}$ curve shift to the right and caused increasing in output.

According to standard IS-LM model, AD-AS model and our VAR estimation model, we found that banks credit has $6.5 \%$ contribution on the variance of Indonesian economic growth. It can be interpreted that $6.5 \%$ of Indonesian economic growth accelerated by banks credit. Banks credit has an important role as growth accelerating factor to Indonesia economy. It means that Indonesian economic growth will be slower when there is an inertia of banking institution on responding the monetary policy by central bank, particularly in interest rate determination.

\section{Conclusion}

Banks credit is a source of economic growth. As an endogenous growth, banks credit has a role as growth accelerating factor to Indonesian economy development, increasing economic growth and reducing both unemployment and poverty rate.

There is bi-direction causality between banks credit revealed by credit depth and economic growth. In the first stage, credit depth promotes economic growth by escalating business in real sector due to the expansion in the availability of capital and liquidity. This expansion increases labor demanded that tends to decrease unemployment rate. The higher the employment will affect the higher the income of society and cause reduction in poverty. In the second stage, economic growth that has occurred will affect deeper financial availability. Banking institution as financial intermediary will be growing up by providing more financial products and services to the market. The higher the credit depth and the financial development will finally make banks to be achieve higher performance. Ultimately, this bi-direction causality will create higher quality of human lives and maintaining financial stability.

Due to the role of Bank Indonesia (BI) as a central bank of Indonesia for monetary stabilization through inflation targeting framework, BI should be able to maintain money view as well as credit view to make sure that commercial banks could drive their role as credit channel. When there is a sustain credit channel mechanism occurs, banks credit would be able to support economic growth, moreover, decreasing both unemployment and poverty on Indonesian economy.

\section{References}

Aghion, P., Angeletos, G M., Banerjee, A., Manova, K. (2010), "Volatility and Growth: Credit Constraints and the Composition of Investment," Journal of Monetary Economics, 57, 246-265.

Arestis, P., Demetriades, P O., Luintel, K B. (2001), "Financial Development and Economic Growth: the Role of Stock Market," Journal of Money, Credit and Banking, 33 (1), 16-41.

Barro, Robert J., and Xavier Sala-i-Martin. 2004. Economic Growth. $2^{\text {nd }}$ Edition. Cambridge, United States: Massachusetts Institute of Technology Press.

Beck, T., Demirguc-Kunt, A., Levine, R. (2000), "Financial Structure and Economic Development: Firm, Industry and Country Evidence," World Bank Policy Research Working Paper, 2423.

Beck T., Levine, R., Loayza, N. (2000), "Finance and the Source of Growth," Journal of Financial Economics, 58, 261-300.

Beck, T., Levine, R. (2004) "Stock Market, Banks and Growth: Panel Evidence," Journal of Banking and Finance, 28, 423-442.

Beck, T., Demirguc-Kunt, A., Laeven, L., Levine, R. (2008) "Finance, Firm Size and Growth," Journal of Money, Credit and Banking, 40 (7), 1279-1405.

Bencivenga, V R., Smith, B D. (1991), "Financial Intermediation and Endogenous Growth," The Review of Economic Studies, 58 (2), 195209. 


\section{Jurnal Ekonomi Pembangunan, 17 (1), Juni 2016, 37-49}

Benhabib, J., Spiegel, M M. (2000), "The Role of Financial Development in Growth and Investment," Journal of Economic Growth, 5, 341-360.

Bernanke, B S. (1993), "Credit in the Macroeconomy," Federal Reserve Bank of New York Quarterly Review, 18 (1), 50-70.

Bernanke, B S., Lown, C S. (1991), "The Credit Crunch," Brooking Papers on Economic Activity, 2, 205-247.

Bernanke, B S., Blinder, A S. (1992), "The Federal Funds Rate and the Channels of Monetary Transmission," The American Economic Review, 82 (4), 901-921.

Bernanke, B S., Gertler, M. (1995), "Inside the Black Box: the Credit Channel of Monetary Policy Transmission," Journal of Economic Perspectives, 9 (4), 27-48.

Bernanke, B S., Mihov, I. (1998), "Measuring Monetary Policy," The Quarterly Journal of Economics, 113 (3), 869-902.

Bernanke, B S., Gertler, M. (1999), "Monetary Policy and Asset Price Volatility," Federal Reserve Bank of Kansas City Economic Review. $4^{\text {th }}$ Quarter, 1-36.

Blanchard, Oliver, and David R. Johnson. 2013. Macroeconomics. $6^{\text {th }}$ Edition. New Jersey, United States, Pearson.

Chodorow-Reich, G. (2014), "The Employment Effects of Credit Market Disruption: FirmLevel Evidence from the 2008-9 Financial Crises," The Quarterly Journal of Economics, 129 (1), 1-60.

Demetriades, P., Hussein, K. (1996), "Does Financial Development Cause Economic Growth? Time Series Evidence from 16 Countries," Journal of Development Economics, 5, 387-411.

Fase, M M G., Abma, R C N. (2003), "Financial Environment and Economic Growth in Selected Asian Countries," Journal of Asian Economics, 14, 11-21.
Fernandez, L., Fernandez, P., Rios, M.A., Matilde. (2012), "Financial Dependence and Economic Growth: SME Evidence," The IEB International Journal of Finance, 4, 100-115.

Jayaratne, J., Strahan, P E. (1996), "Finance Growth Nexus: Evidence from Bank Branch Regulation," The Quarterly Journal of Economics, 111 (3), 639-670.

King, R G., Levine, R. (1993a), "Finance, Entrepreneurship and Growth - Theory and Evidence," Journal of Monetary Economics, 32, 513-542.

King, R G., Levine, R. (1993b), "Finance and Growth: Schumpeter Might be Right," The Quarterly Journal of Economics, 108 (3), 717-737.

Levine, R. (1997), "Financial Development and Economic Growth: Views and Agenda," Journal of Economic Literature, 35, 688-726.

Levine, R. (2003) "More on Finance and Growth: More Finance, More Growth?" The Federal Reserve Bank of St. Louis, July/August.

Levine, R., Zervos, S. (1998), "Stock Market, Banks and Economic Growth," The American Economic Review, 88 (3), 537-558.

Levine, R., Loayza, N., Beck, T. (2000), "Financial Intermediation and Growth: Causality and Causes," Journal of Monetary Economics, 46, 31-77.

Pagano, M. (1993), "Financial Markets and Growth - an Overview," European Economic Review, 37, 613-622.

Rioja, F., Valev, N. (2014), Stock Markets, Banks and the Sources of Economic Growth in Low and High Income Countries," Journal of Economic and Finance, 38 (2), 302-320.

Woodford, M. (2010) "Financial Intermediation and Macroeconomic Analysis," Journal of Economic Perspectives, 24 (1), 21-44. 
Avalaible online at http://journals.ums.ac.id

\section{Jurnal Ekonomi Pembangunan, 17 (1), Juni 2016, 37-49}

\section{Appendix}

Appendix 1. VAR model estimation on the relationship between credit depth (CRE) and real GDP growth per capita (NGR)

\section{Vector Auto-Regression Estimates}

Sample (adjusted): 19932014

Included observations: 22 after adjustments

Standard errors in ( ) \& t-statistics in []

\begin{tabular}{|c|c|c|}
\hline & $\Delta \mathrm{NGR}$ & $\Delta \mathrm{CRE}$ \\
\hline \multirow[t]{3}{*}{$\Delta \mathrm{NGR}_{-1}$} & -0.757464 & -0.447334 \\
\hline & $(0.17568)$ & $(0.09480)$ \\
\hline & {$[-4.31164]$} & {$[-4.71875]$} \\
\hline \multirow[t]{3}{*}{$\Delta \mathrm{CRE}_{-1}$} & 0.682732 & 0.578140 \\
\hline & $(0.29946)$ & $(0.16160)$ \\
\hline & [ 2.27985] & [ 3.57770] \\
\hline \multirow[t]{3}{*}{$\mathrm{C}$} & 0.291456 & -0.190715 \\
\hline & $(1.98207)$ & $(1.06956)$ \\
\hline & {$[0.14705]$} & {$[-0.17831]$} \\
\hline R-squared & 0.500473 & 0.576766 \\
\hline Adj. R-squared & 0.447891 & 0.532215 \\
\hline Sum sq. Resids & 1629.263 & 474.4184 \\
\hline S.E. equation & 9.260166 & 4.996938 \\
\hline F-statistic & 9.517984 & 12.94619 \\
\hline Log likelihood & -78.56989 & -64.99817 \\
\hline Akaike AIC & 7.415445 & 6.181652 \\
\hline Schwarz SC & 7.564223 & 6.330430 \\
\hline Mean dependent & -0.044700 & -0.495436 \\
\hline S.D. dependent & 12.46253 & 7.306017 \\
\hline Determinant resid covariance (dof adj.) & & 1947.028 \\
\hline Determinant resid covariance & & 1452.225 \\
\hline Log likelihood & & -142.5227 \\
\hline Akaike information criterion & & 13.50206 \\
\hline Schwarz criterion & & 13.79962 \\
\hline
\end{tabular}


Avalaible online at http://journals.ums.ac.id

\section{Jurnal Ekonomi Pembangunan, 17 (1), Juni 2016, 37-49}

Appendix 2. Granger causality on the relationship between credit depth (CRE) and real GDP growth per capita (NGR)

Pairwise Granger Causality Tests

Sample: 19912014

Lags: 1

\begin{tabular}{lccc}
\hline Null Hypothesis: & Obs & F-Statistic & Prob. \\
\hline CRE does not Granger Cause NGR & 23 & 4.06563 & 0.0574 \\
NGR does not Granger Cause CRE & & 30.2505 & 2. E-05 \\
\hline
\end{tabular}

Appendix 3. Regression in difference model estimation on the relationship between credit depth (CRE) and unemployment rate (NUNE)

Dependent Variable: NUNE

Method: Least Squares

Sample (adjusted): 19922014

\begin{tabular}{lclcc}
\hline \multicolumn{1}{c}{ Variable } & Coefficient & \multicolumn{1}{c}{ Std. Error } & t-Statistic & Prob. \\
\hline \multicolumn{1}{c}{ CRE $_{-1}$} & -0.129099 & 0.024023 & -5.374071 & 0.0000 \\
C & 11.58332 & 0.881091 & 13.14657 & 0.0000 \\
\hline R-squared & 0.578995 & Mean dependent var & & 7.169565 \\
Adjusted R-squared & 0.558947 & S.D. dependent var & 2.303798 \\
S.E. of regression & 1.529994 & Akaike info criterion & 3.771346 \\
Sum squared resid & 49.15852 & Schwarz criterion & 3.870085 \\
Log likelihood & -41.37048 & Hannan-Quinn criter. & 3.796179 \\
F-statistic & 28.88064 & Durbin-Watson stat & & 1.103677 \\
Prob(F-statistic) & 0.000025 & & & \\
\hline
\end{tabular}

Appendix 4. ECM estimation on the relationship between credit depth (CRE) and unemployment rate (NUNE)

Dependent Variable: $\triangle$ NUNE

Method: Least Squares

Sample (adjusted): 19932014

\begin{tabular}{lcccc}
\hline \multicolumn{1}{c}{ Variable } & Coefficient & Std. Error & t-Statistic & Prob. \\
\hline \multicolumn{1}{c}{$\Delta \mathrm{CRE}_{-1}$} & -0.013925 & 0.032061 & -0.434320 & 0.6689 \\
ET $_{-1}$ & -0.521164 & 0.154809 & -3.366506 & 0.0032 \\
\multicolumn{1}{c}{} & 0.161647 & 0.226416 & 0.713936 & 0.4839 \\
\hline R-squared & 0.374137 & Mean dependent var & & 0.147273 \\
Adjusted R-squared & 0.308257 & S.D. dependent var & 1.272145 \\
S.E. of regression & 1.058057 & Akaike info criterion & 3.076870 \\
Sum squared resid & 21.27022 & Schwarz criterion & 3.225648 \\
Log likelihood & -30.84557 & Hannan-Quinn criter. & & 3.111918 \\
F-statistic & 5.679047 & Durbin-Watson stat & & 1.790980 \\
Prob(F-statistic) & 0.011656 & & & \\
\hline
\end{tabular}


Avalaible online at http://journals.ums.ac.id

\section{Jurnal Ekonomi Pembangunan, 17 (1), Juni 2016, 37-49}

Appendix 5. Regression model estimation on the relationship between credit depth (CRE) and poverty rate (NPOV)

Dependent Variable: NPOV

Method: Least Squares

Sample (adjusted): 19922014

\begin{tabular}{lcccc}
\hline \multicolumn{1}{c}{ Variable } & Coefficient & \multicolumn{1}{c}{ Std. Error } & t-Statistic & Prob. \\
\hline \multicolumn{1}{c}{$\Delta$ CRE } & -0.323209 & 0.081550 & -3.963314 & 0.0007 \\
C & 15.56963 & 0.572031 & 27.21817 & 0.0000 \\
\hline R-squared & 0.427915 & Mean dependent var & 15.75522 \\
Adjusted R-squared & 0.400673 & S.D. dependent var & 3.531762 \\
S.E. of regression & 2.734156 & Akaike info criterion & 4.932464 \\
Sum squared resid & 156.9878 & Schwarz criterion & 5.031202 \\
Log likelihood & -54.72333 & Hannan-Quinn criter. & 4.957296 \\
F-statistic & 15.70786 & Durbin-Watson stat & & 0.996080 \\
Prob(F-statistic) & 0.000709 & & & \\
\hline
\end{tabular}

Appendix 6. ECM estimation on the relationship between credit depth (CRE) and poverty rate (NPOV)

Dependent Variable: $\triangle \mathrm{NPOV}$

Method: Least Squares

Sample (adjusted): 19932014

Included observations: 22 after adjustments

\begin{tabular}{|c|c|c|c|c|}
\hline Variable & Coefficient & Std. Error & t-Statistic & Prob. \\
\hline $\mathrm{C}$ & -0.165976 & 0.458237 & -0.362205 & 0.7212 \\
\hline$\Delta \mathrm{CRE}$ & -0.139009 & 0.077476 & -1.794232 & 0.0887 \\
\hline$\Delta \mathrm{ET}_{-1}$ & 0.560690 & 0.207714 & 2.699339 & 0.0142 \\
\hline $\mathrm{R}$-squared & 0.280219 & Mean dependent var & & -0.175000 \\
\hline Adjusted R-squared & 0.204452 & S.D. dependent var & & 2.403646 \\
\hline S.E. of regression & 2.143895 & Akaike info criterion & & 4.489249 \\
\hline Sum squared resid & 87.32943 & Schwarz criterion & & 4.638028 \\
\hline Log likelihood & -46.38174 & Hannan-Quinn criter. & & 4.524297 \\
\hline F-statistic & 3.698456 & Durbin-Watson stat & & 1.619371 \\
\hline Prob(F-statistic) & 0.043995 & & & \\
\hline
\end{tabular}

